$\xi=$

\title{
Isolation of Four Flavanones from the Leaves of Macaranga Hypoleuca (Rchb.f. \& Zoll.) Müll.Arg
}

\author{
H. Muhamad Nazeri ${ }^{1,2}$, N. Ahmat ${ }^{1,2^{*}}$ K. Abdul Khalil \\ ${ }^{I}$ Faculty of Applied Sciences, UiTM Shah Alam, 40450 Shah Alam, Selangor, Malaysia \\ ${ }^{2}$ Atta-ur-Rahman Institute for Natural Product Discovery, Universiti Teknologi MARA (UiTM), Puncak Alam Campus, 42300 Bandar \\ Puncak Alam, Selangor, Malaysia \\ *Corresponding author E-mail: noriz11@salam.uitm.edu.my
}

\begin{abstract}
Macaranga is a large genus belongs to Euphorbiaceae family which commonly distributed in the tropical region of Africa, South-East Asia, China, and India. The plant of this genus contain flavonoids and stilbenes bearing various terpenyl groups including prenyl, geranyl and farnesyl groups. The leaves of $M$. hypoleuca were collected from reserved forest UiTM Jengka Pahang, Malaysia, and the dried powdered leaves were macerated in methanol at room temperature. The crude methanol extract was subjected to liquid-liquid partition using $n$-hexane and ethyl acetate to obtain hexane, ethyl acetate and aqueous fractions. The ethyl acetate fraction was semi purified using vacuum liquid chromatography (VLC) to give nine major fractions (MHL1-MHL9). Fraction MHL3 was further purified by column chromatography (CC) and preparative thin layer chromatography (p-TLC) to give two pure compounds, 8-prenylnaringenin (1) and sakuranetin (5,4'-dihydroxy-7-methoxyflavanone) (3). Meanwhile, fraction MHL6 was purified using column chromatography (CC) and p-TLC to yield another two pure compounds, 6-(3-hydroxy-3-methyl)naringenin (2) and 7-O-methyleriodictyol (4). The chemical structure of these isolated compounds were determined based on their 1D and 2D NMR, UV, and IR data. From this study, four flavanones were isolated from the leaves of $M$. hypoleuca.
\end{abstract}

Keywords: Euphorbiaceae; flavonoid; flavanone; Macaranga hypoleuca; phenolic compound

\section{Introduction}

Euphorbiaceae is among the largest family of angiosperms flowering plant composed of over 300 genera [1], with Macaranga as the major genus consisting approximately 300 species [2]. Out of 280 Macaranga species worldwide, 27 species are broadly distributed in Malaysia where the plants usually grow in a place with a lot of sunlight in secondary or damaged forest as well as in village area, wastelands and swampy forests [3], [4]. Many plant parts of Macaranga species are widely used in traditional medicine, for example the dried root of $M$. tanarius was used as emetic agent, meanwhile the decoction of the root was used as an antipyretic as well as an antitussive in Malaysian and Thailand medicinal remedies. In addition, the leaves part of this species was used as antiinflammatory for wound healing [5]-[7]. This genus is known to be rich source of prenylated flavonoids and stilbenoids which regarded as the major constituent possessed a wide range of biological activities. This includes anticancer [8], antioxidant [5], [9], antimicrobial [6], anti-inflammatory [10] and other different types of bioactivities.

\section{Material and method}

\subsection{Characterization}

The characterization of pure compounds (1-4) was done by using infrared (IR), ultraviolet-visible (UV-Vis), one and two dimensional nuclear magnetic resonance (1D and 2D NMR) spectros- copy. The NMR experiment was done in acetone- $d_{6}$ and chemical shift values are reported in ppm and shown as $\delta$ scale.

\subsection{Plant material}

The leaves and stem bark of Macaranga hypoleuca were collected from Hutan Simpan UiTM Jengka, Pahang and identified by a botanist from Universiti Teknologi MARA (UiTM) Shah Alam.

\subsection{Extraction and isolation}

The ground, air-dried leave of M. hypoleuca $(2.5 \mathrm{~kg})$ was macerated in methanol $(10 \mathrm{~L})$ for 24 hours and repeated for three times. The crude methanol extract was then subjected to liquid-liquid partition using n-hexane and ethyl acetate successively. The ethyl acetate fraction $(370 \mathrm{~g})$ was fractionated using vacuum liquid chromatography (VLC) eluted with the mixtures of n-hexane and EtOAc with increasing polarity to give eight major fractions (HL1-HL8). $444 \mathrm{mg}$ of HL3 was further fractionated using column chromatography (CC) over Sephadex-LH20 gel with solvent system $\mathrm{CHCl}_{3}$ : $\mathrm{MeOH}$ (50: 50) yielded six subfractions (HL31HL36). HL35 (100.4 mg) was subjected to column chromatography (CC) over silica gel and eluted with mixture of Hex: EtOAc, followed by EtOAc: $\mathrm{MeOH}$ to yield eight fractions (HL351HL358). Further purification of fraction HL355 (17.3 mg) and HL354 (25.1 mg) using preparative thin layer chromatography (pTLC) with solvent system Hex: Acetone yielded (1) (7 mg) and (3) (10 mg). 
$10.6 \mathrm{~g}$ of HL6 was fractionated using VLC and eluted with the mixture of Hex: EtOAc and followed by EtOAc: $\mathrm{MeOH}$ to give eight fractions (HL61-HL68). Fraction HL65 was further fractionated and isolated by Sephadex-LH20 gel column (twice), column chromatography $(\mathrm{CC})$ over silica gel $\left(\mathrm{CHCl}_{3}\right.$ : EtOAc), radial chromatography $\left(\mathrm{CHCl}_{3}: \mathrm{MeOH}\right)$ and p-TLC $\left(\mathrm{CHCl}_{3}: \mathrm{MeOH}\right)$ to yield (2) $(6.5 \mathrm{mg})$. Compound (4) $(2 \mathrm{mg})$ was obtained from the separation of HL64 (2.05 g) using Sephadex-LH20 gel column $(\mathrm{MeOH})$, column chromatography $(\mathrm{CC})$ over silica gel (Hex: Acetone) and p-TLC (Hex: EtOAc).

8-prenylnaringenin (1). Yellow sticky solid. UV (MeOH) $\lambda_{\max } \mathrm{nm}$ : 226.4, 242, 293.2, 340.4; ATR-IR $v_{\max } \mathrm{cm}^{-1}: 3313(\mathrm{OH}), 1635$ $(\mathrm{C}=\mathrm{O}), 1612(\mathrm{C}=\mathrm{C}), 1077$; ${ }^{1} \mathrm{H}-\mathrm{NMR}$ (Acetone- $\left.d_{6}, 600 \mathrm{MHz}\right) \delta$ ppm : $12.16(1 \mathrm{H}, \mathrm{s}, \mathrm{OH}-5), 7.43\left(2 \mathrm{H}, \mathrm{d}, \mathrm{J}=8.4 \mathrm{~Hz}, \mathrm{H}-2^{\prime} / \mathrm{H}^{\prime}-6^{\prime}\right)$, $6.93(2 \mathrm{H}, \mathrm{d}, \mathrm{J}=8.4 \mathrm{~Hz}, \mathrm{H}-3$ ' $/ \mathrm{H}-5$ ') $6.05(1 \mathrm{H}, \mathrm{s}, \mathrm{H}-6), 5.46(1 \mathrm{H}$, $\mathrm{dd}, \mathrm{J}=13.2,3 \mathrm{~Hz}, \mathrm{H}-2), 3.16(1 \mathrm{H}, \mathrm{dd}, \mathrm{J}=12.8,16.8 \mathrm{~Hz}, \mathrm{H}-3 \mathrm{~b})$, $2.76(1 \mathrm{H}, \mathrm{dd}, \mathrm{J}=16.8,3 \mathrm{~Hz}, \mathrm{H}-3 \mathrm{a}), 5.21(1 \mathrm{H}, \mathrm{d}, \mathrm{J}=7.2 \mathrm{~Hz}, \mathrm{H}-2$ ''), $3.23(2 \mathrm{H}, \mathrm{d}, \mathrm{J}=7.2 \mathrm{~Hz}, \mathrm{H}-1$ ' $), 1.62\left(6 \mathrm{H}, \mathrm{s}, \mathrm{H}-4{ }^{\prime \prime} / \mathrm{H}-5{ }^{\prime \prime}\right) ;{ }^{13} \mathrm{C}-$ NMR (Acetone- $\left.d_{6}, 150 \mathrm{MHz}\right) \delta$ ppm: $79.71(\mathrm{C}-2), 43.41(\mathrm{C}-3)$, 197.55 (C-4), 162.94 (C-5), 96.41 (C-6), 165.47 (C-7), 108.35 (C8), 161.03 (C-9), 103.13 (C-10), 130.89 (C-1'), 128.78 (C-2\%/C6'), 116.18 (C-3'/C-5'), 158.76 (C-4'), 22.25 (C-1''), 123.78 (C2'”), 131.13 (C-3"'), 17.86 (C-4"'), 25.88 (C-5"') [11].

6-(3-hydroxy-3-methyl)naringenin (2). Brown sticky solid. UV $(\mathrm{MeOH}) \lambda_{\max } \mathrm{nm}: 224.4,293.2$, 339.5; IR $v_{\max } \mathrm{cm}^{-1}: 3214(\mathrm{OH})$, $1629(\mathrm{C}=\mathrm{O}), 1610(\mathrm{C}=\mathrm{C}), 1076 ;{ }^{1} \mathrm{H}-\mathrm{NMR}$ (Acetone- $d_{6}, 600 \mathrm{MHz}$ ) $\delta$ ppm : $12.13(1 \mathrm{H}, \mathrm{s}, \mathrm{OH}-5), 7.37$ (2H, d, J = 9 Hz, H-2'/H-6'), $6.84\left(2 \mathrm{H}, \mathrm{d}, \mathrm{J}=9 \mathrm{~Hz}, \mathrm{H}-3^{\prime} / \mathrm{H}^{\prime} 5^{\prime}\right), 5.95(1 \mathrm{H}, \mathrm{s}, \mathrm{H}-8), 5.37(1 \mathrm{H}, \mathrm{dd}$, $\mathrm{J}=12.6,2.4 \mathrm{~Hz}, \mathrm{H}-2), 3.08(1 \mathrm{H}, \mathrm{dd}, \mathrm{J}=16.8,12.6 \mathrm{~Hz}, \mathrm{H}-3 \mathrm{~b}), 2.76$ $(1 \mathrm{H}, \mathrm{dd}, \mathrm{J}=17.4,3 \mathrm{~Hz}, \mathrm{H}-3 \mathrm{a}), 1.63(2 \mathrm{H}, \mathrm{m}, \mathrm{H}-2$ '”), 2.59 (2H, d, J $=7.2 \mathrm{~Hz}, \mathrm{H}-1$ ' ') 1.19 (6H, s, H-4"'/H-5"') [12]; ${ }^{13} \mathrm{C}-\mathrm{NMR}$ (Acetone- $\left.d_{6}, 150 \mathrm{MHz}\right) \delta$ ppm: $78.56(\mathrm{C}-2), 42.53(\mathrm{C}-3), 196.69(\mathrm{C}-4)$, 161.97 (C-5), 108.66 (C-6), 164.27 (C-7), 95.73 (C-8), 160.17 (C9), 102.46 (C-10), 130.26 (C-1'), 127.781(C-2'/C-6'), 115.25 (C3'/C-5'), 157.60 (C-4'), 17.36 (C-1'”), 42.93 (C-2''), 69.67 (C-3'”), 28.56 (C-4"'/C-5').

Sakuranetin (5,4'-dihydroxy-7-methoxyflavanone) (3). White solid. UV (MeOH) $\lambda \max \mathrm{nm}: 230,286,331$; IR vmax cm-1: 3346 $(\mathrm{OH}), 1639(\mathrm{C}=\mathrm{O}), 1616(\mathrm{C}=\mathrm{C}), 1156 ;{ }^{1} \mathrm{H}-\mathrm{NMR}$ (Acetone-d6, 600 MHz) $\delta$ ppm: $12.16(1 \mathrm{H}, \mathrm{s}, 5-\mathrm{OH}), 5.51(1 \mathrm{H}, \mathrm{dd}, \mathrm{J}=13.2,3 \mathrm{~Hz}, \mathrm{H}-$ 2), $2.79(1 \mathrm{H}, \mathrm{dd}, \mathrm{J}=16.8,3 \mathrm{~Hz}, \mathrm{H}-3 \mathrm{a}), 3.24(1 \mathrm{H}, \mathrm{dd}, \mathrm{J}=16.8,13.2$ $\mathrm{Hz}, \mathrm{H}-3 \mathrm{~b}), 6.06(1 \mathrm{H}, \mathrm{d}, \mathrm{J}=2.4 \mathrm{~Hz}, \mathrm{H}-6), 6.07(1 \mathrm{H}, \mathrm{d}, \mathrm{J}=2.4 \mathrm{~Hz}$, H-8), $7.42\left(2 \mathrm{H}, \mathrm{d}, \mathrm{J}=8.4 \mathrm{~Hz}, \mathrm{H}-2^{\prime} / \mathrm{H}_{-} 6^{\prime}\right), 6.92(2 \mathrm{H}, \mathrm{d}, \mathrm{J}=9 \mathrm{~Hz}, \mathrm{H}-$ 3'/H-5'), $3.86\left(3 \mathrm{H}, \mathrm{s}, \mathrm{OCH}_{3}\right) ;{ }^{13} \mathrm{C}-\mathrm{NMR}$ (Acetone-d6, $\left.150 \mathrm{MHz}\right) \delta$ ppm: 80.05 (C-2), 43.52 (C-3), 197.59 (C-4), 165.03 (C-5), 95.49 (C-6), 168.91 (C-7), 94.58 (C-8), 164.22 (C-9), 103.79 (C-10), 130.69 (C-1'), 128.96 (C-2'/C-6'), 116.22 (C-3'/C-5'), 158.78 (C4 '), $56.21\left(\mathrm{C}-\mathrm{OCH}_{3}\right)[13]$.

7-O-methyleriodictyol (4). Dark yellow sticky solid. UV (MeOH) $\lambda \max$ nm: 230, 287, 332; ${ }^{1} \mathrm{H}-\mathrm{NMR}$ (Acetone-d6, $\left.600 \mathrm{MHz}\right) \delta \mathrm{ppm}$ : $12.16(1 \mathrm{H}, \mathrm{s}, \mathrm{OH}-5), 5.45(1 \mathrm{H}, \mathrm{dd}, \mathrm{J}=12.6,3 \mathrm{~Hz}, \mathrm{H}-2), 3.19(1 \mathrm{H}$ $\mathrm{dd}, \mathrm{J}=12.8,16.8 \mathrm{~Hz}, \mathrm{H}-3 \mathrm{a}), 2.76(1 \mathrm{H}, \mathrm{dd}, \mathrm{J}=16.8,3 \mathrm{~Hz}, \mathrm{H}-3 \mathrm{~b})$, $6.05(1 \mathrm{H}, \mathrm{d}, \mathrm{J}=2.4 \mathrm{~Hz}, \mathrm{H}-6), 6.07(1 \mathrm{H}, \mathrm{d}, \mathrm{J}=2.4 \mathrm{~Hz}, \mathrm{H}-8), 7.05$ (1H, s, H-2'), 6.88 (2H, s, H-5'/H-6'), 3.86 (3H, s, $\left.\mathrm{OCH}_{3}\right)$ [14]; ${ }^{13} \mathrm{C}-\mathrm{NMR}$ (Acetone-d6, $\left.150 \mathrm{MHz}\right) \delta \mathrm{ppm}$ : 79.20 (C-2), $42.68(\mathrm{C}-$ 3), 196.74 (C-4), 164.10 (C-5), 94.53 (C-6), 167.97 (C-7), 93.66 (C-8), 163.30 (C-9), 102.88 (C-10), 130.49 (C-1'), 113.92 (C-2'), 145.29 (C-3'), 145.68 (C-4'), 115.22 (C-5'), 118.28 (C-6'), 55.32 $\left(\mathrm{C}-\mathrm{OCH}_{3}\right)$

\section{Results and Discussion}

Compound 1-4 (Figure 1) were successfully isolated from the methanolic leaves extract of $M$. hypoleuca and compound 2-4 were first time isolated from genus Macaranga. Compound (1) was obtained as yellowish sticky solid. The UV spectrum of this compound displayed maximum absorption at $\lambda_{\max } 226,242,293$ and $340 \mathrm{~nm}$ and IR spectrum showed absorption bands at 3313 $\mathrm{cm}^{-1}$ (broad, $\left.\mathrm{OH}\right), 1635 \mathrm{~cm}^{-1}$ (C=O carboxylate), $1612 \mathrm{~cm}^{-1}(\mathrm{C}=\mathrm{C})$ and $1077 \mathrm{~cm}^{-1}$ (C-O). The ${ }^{1} \mathrm{H}$ NMR spectrum of (1) displayed a typical characteristic for a flavanone by the presence of methylene proton signals at $\delta_{\mathrm{H}} 3.16(1 \mathrm{H}, \mathrm{dd}, \mathrm{J}=12.8,16.8 \mathrm{~Hz}, \mathrm{H}-3 \mathrm{~b}), \delta_{\mathrm{H}} 2.76$ $(1 \mathrm{H}, \mathrm{dd}, \mathrm{J}=16.8,3 \mathrm{~Hz}, \mathrm{H}-3 \mathrm{a})$ and one oxymethine proton at $\delta_{\mathrm{H}}$ $5.46(1 \mathrm{H}, \mathrm{dd}, \mathrm{J}=13.2,3 \mathrm{~Hz}, \mathrm{H}-2)$. One singlet proton signal observed at $\delta_{\mathrm{H}} 6.05(1 \mathrm{H})$ which belongs to $\mathrm{H}-6$ indicated that ring $\mathrm{A}$ is a pentasubstituted ring system. The appearance of an aliphatic methylene proton at $\delta_{\mathrm{H}} 3.23(2 \mathrm{H}, \mathrm{d}, \mathrm{J}=7.2 \mathrm{~Hz}, \mathrm{H}-1$ ' $)$, one vinyl proton at $\delta_{\mathrm{H}} 5.21(1 \mathrm{H}, \mathrm{d}, \mathrm{J}=7.2 \mathrm{~Hz}, \mathrm{H}-2$ "') and two olefinic methyl groups at $\delta_{\mathrm{H}} 1.62(6 \mathrm{H}, \mathrm{s}, \mathrm{H}-4$ "'/H-5') showed the presence of prenyl group. At ring $\mathrm{B}$, two set of ortho-coupled aromatic methine protons at $\delta_{\mathrm{H}} 7.43\left(2 \mathrm{H}, \mathrm{d}, \mathrm{J}=8.4 \mathrm{~Hz}, \mathrm{H}-2^{\prime} / \mathrm{H}^{\prime} 6^{\prime}\right)$ and $\delta_{\mathrm{H}}$ $6.93\left(2 \mathrm{H}, \mathrm{d}, \mathrm{J}=8.4 \mathrm{~Hz}, \mathrm{H}-3^{\prime} / \mathrm{H}^{-} 5^{\prime}\right)$ indicated the presence of AABB spin system. In addition, the signal for a chelated $\mathrm{OH}$ observed at a very downfield region at $\delta_{\mathrm{H}} 12.16(1 \mathrm{H}, \mathrm{s}, \mathrm{OH}-5)$ is due to hydrogen bonding between hydroxyl group at C-5 and carbonyl group at C-4. The ${ }^{13} \mathrm{C}$ NMR APT displayed 18 carbon signals which represent a total of 20 carbons. One aliphatic methylene carbon appeared at $\delta_{\mathrm{C}} 43.41(\mathrm{C}-3)$ and one oxymethine carbon at $\delta_{\mathrm{C}} 79.71(\mathrm{C}-2)$ showed that $(\mathbf{1})$ is a flavanone. Other signals are four oxyaryl carbons $\left(\delta_{\mathrm{C}} 158.76-165.47\right)$, three aromatic quartenary carbons $\left(\delta_{\mathrm{C}} 103.13,108.35,130.89\right)$, five methine carbons $\left(\delta_{\mathrm{C}} 96.41,116.18,128.78\right)$ and carbonyl carbon $\left(\delta_{\mathrm{C}} 197.55\right)$. In addition, carbon signals for prenyl group appeared at $\delta_{\mathrm{C}} 17.86$ (C-4”), 22.25 (C-1"), 25.88 (C-5"), 123.78 (C-2") and 131.13 (C3 "). Based on spectral data and comparison with literature data, compound 1 was assigned as 8-prenylnaringenin.

Previously, 8-prenylnaringenin was isolated from M. kurzii and was evaluated against human lung carcinoma (A-549) and humanhepatocellular (Hep G2) cell lines by MTTmethod. The results showed that 8-prenylnaringenin inhibited the proliferation of A549 cell line with IC50 values of $9.76 \mu \mathrm{g} / \mathrm{mL}$ [15].

Compound (2) was isolated as brownish sticky solid. The UV spectrum of this compound displayed maximum absorption at $\lambda_{\max }$ 224, 293 and $339 \mathrm{~nm}$ and IR spectrum showed absorption bands at $3214 \mathrm{~cm}^{-1}$ (broad, $\left.\mathrm{OH}\right), 1629 \mathrm{~cm}^{-1}$ ( $\mathrm{C}=\mathrm{O}$ carboxylate), $1610 \mathrm{~cm}^{-1}$ $(\mathrm{C}=\mathrm{C})$ and $1076 \mathrm{~cm}^{-1}(\mathrm{C}-\mathrm{O})$. The ${ }^{1} \mathrm{H}$ NMR spectrum of (2) exhibited similar signal pattern to that of compound (1) in the presence of methylene proton at $\delta_{\mathrm{H}} 3.08(1 \mathrm{H}, \mathrm{dd}, \mathrm{J}=12.6,16.8 \mathrm{~Hz}, \mathrm{H}-3 \mathrm{~b})$, $\delta_{\mathrm{H}} 2.76(1 \mathrm{H}, \mathrm{dd}, \mathrm{J}=17.4,3 \mathrm{~Hz}, \mathrm{H}-3 \mathrm{a})$ and one oxymethine proton at $\delta_{\mathrm{H}} 5.37(1 \mathrm{H}, \mathrm{dd}, \mathrm{J}=12.6,2.4 \mathrm{~Hz}, \mathrm{H}-2)$ as key characteristic for flavanone. The difference between the ${ }^{1} \mathrm{H}$ NMR spectrum of 2 and 1 can be observed in ring A where the prenyl group occupied the C-6 of compound $\mathbf{2}$ instead of at C-8 in compound $\mathbf{1}$. However, the prenyl group that attached to C- 6 is a hydroxylated prenyl group which can be seen by the presence of methylene proton signal at $\delta_{\mathrm{H}} 1.63\left(2 \mathrm{H}, \mathrm{m}, \mathrm{H}-2\right.$ "') instead of vinyl proton at $\delta_{\mathrm{H}} 5.21$ $(1 \mathrm{H}, \mathrm{d}, \mathrm{J}=7.2 \mathrm{~Hz}, \mathrm{H}-2$ '') in compound 1 . Two set of orthocoupled aromatic methine protons at $\delta_{\mathrm{H}} 7.37(2 \mathrm{H}, \mathrm{d}, \mathrm{J}=9 \mathrm{~Hz}, \mathrm{H}-$ 2'/H-6') and $\delta_{\mathrm{H}} 6.84\left(2 \mathrm{H}, \mathrm{d}, \mathrm{J}=9 \mathrm{~Hz}, \mathrm{H}-3^{\prime} / \mathrm{H}-5\right.$ ') indicated the presence of $\mathrm{AABB}$ spin system at ring $\mathrm{B}$. One singlet signal located at a very downfield region at $\delta_{\mathrm{H}} 12.13(1 \mathrm{H}, \mathrm{s}, \mathrm{OH}-5)$ indicated the chelated $\mathrm{OH}$ at $\mathrm{C}-5$ due to hydrogen bonding between hydrogen and oxygen atom of carbonyl group at $\mathrm{C}-4$. The ${ }^{13} \mathrm{C}$ NMR APT displayed 17 carbon signals which represent a total of 20 carbons. One aliphatic methylene carbon appeared at $\delta_{\mathrm{C}} 42.53$ (C3 ) and one oxymethine carbon at $\delta_{C} 78.56(\mathrm{C}-2)$ showed that (2) is a flavanone. Other signals are four oxyaryl carbons $\left(\delta_{\mathrm{C}} 157.60-\right.$ $164.27)$, three aromatic quartenary carbons $\left(\delta_{\mathrm{C}} 102.46,108.66\right.$, $130.26)$, five methine carbons $\left(\delta_{C} 95.73,115.25,127.70\right)$ and carbonyl carbon $\left(\delta_{\mathrm{C}} 196.69\right)$. In addition, carbon signals for prenyl group appeared at $\delta_{\mathrm{C}} 17.36$ (C-1"), 28.56 (C-4"/C-5”), 42.93 (C$2 ")$ and 69.67 (C-3"). Based on spectral data and comparison with previous reported data, compound 2 was determined as 6-(3hydroxy-3-methyl)naringenin and was first time been isolated from plant.

Compound (3) was obtained as white solid. The UV spectrum of this compound displayed maximum absorption at $\lambda \max 230,286$ and $331 \mathrm{~nm}$ and IR spectrum showed absorption bands at 3346 $\mathrm{cm}^{-1}$ (broad, OH), $1639 \mathrm{~cm}^{-1}$ (C=O carboxylate), $1616 \mathrm{~cm}^{-1}(\mathrm{C}=\mathrm{C})$ 
and $1156 \mathrm{~cm}^{-1}$ (C-O). The ${ }^{1} \mathrm{H}$ NMR spectrum of (3) displayed a typical characteristic for a flavanone by the presence of methylene proton signals at $\delta_{\mathrm{H}} 2.79(1 \mathrm{H}, \mathrm{dd}, \mathrm{J}=16.8,3 \mathrm{~Hz}, \mathrm{H}-3 \mathrm{a}), 3.24(1 \mathrm{H}$, $\mathrm{dd}, \mathrm{J}=16.8,13.2 \mathrm{~Hz}, \mathrm{H}-3 \mathrm{~b}$ ) and one oxymethine proton at $\delta_{\mathrm{H}} 5.51$ $(1 \mathrm{H}, \mathrm{dd}, \mathrm{J}=13.2,3 \mathrm{~Hz}, \mathrm{H}-2)$. Two meta coupled aromatic protons was spotted at $\delta_{\mathrm{H}} 6.06(1 \mathrm{H}, \mathrm{d}, \mathrm{J}=2.4 \mathrm{~Hz})$ and $6.07(1 \mathrm{H}, \mathrm{d}, \mathrm{J}=2.4$ $\mathrm{Hz}$ ) belongs to $\mathrm{H}-6$ and $\mathrm{H}-8$ of a di-substituted (at C-5 and C-7) ring $\mathrm{A}$. The ${ }^{1} \mathrm{H}$ NMR spectrum displayed the appearance of an AABB spin system at $\delta_{\mathrm{H}} 7.42\left(2 \mathrm{H}, \mathrm{d}, \mathrm{J}=8.4 \mathrm{~Hz}, \mathrm{H}-2^{\prime} / \mathrm{H}^{\prime} 6^{\prime}\right)$ and $6.92(2 \mathrm{H}, \mathrm{d}, \mathrm{J}=9 \mathrm{~Hz}, \mathrm{H}-3$ ' $/ \mathrm{H}-5$ ') consistent with 4'-substituted ring B. Furthermore, one signal was observed at $\delta_{\mathrm{H}} 3.86(3 \mathrm{H}, \mathrm{s})$ which was assigned to methoxyl group located at C-7 as established from HMBC spectrum, which showed correlation between methoxyl proton at $\delta_{\mathrm{H}} 3.86$ with $\mathrm{C}-7\left(\delta_{\mathrm{C}} 56.21\right)$. In addition, the ${ }^{1} \mathrm{H}$ spectrum also displayed the presence of chelated $\mathrm{OH}$ at a very downfield region at $\delta_{\mathrm{H}} 12.16(1 \mathrm{H}, \mathrm{s}, \mathrm{OH}-5)$ which was due to hydrogen bonding between hydroxyl group at C-5 and carbonyl group at C-4. The ${ }^{13} \mathrm{C}$ NMR APT displayed 14 carbon signals which represent a total of 16 carbons. One aliphatic methylene carbon appeared at $\delta_{\mathrm{C}} 43.41(\mathrm{C}-3)$ and one oxymethine carbon at $\delta_{\mathrm{C}} 79.71(\mathrm{C}-2)$ showed that $(3)$ is a flavanone. Other signals are four oxyaryl carbons $\left(\delta_{\mathrm{C}} 158.78-168.90\right)$, two aromatic quartenary carbons $\left(\delta_{\mathrm{C}} 103.79\right.$ and 130.69$)$, six methine carbons $\left(\delta_{\mathrm{C}} 94.58\right.$, $95.49,116.22,128.98)$ and carbonyl carbon $\left(\delta_{\mathrm{C}} 197.59\right)$. In addition, carbon signals for methoxyl group appeared at $\delta_{\mathrm{C}} 56.21$ (C$\mathrm{OCH}_{3}$ ). Based on spectral data and comparison with literature data, compound $\mathbf{3}$ was assigned as Sakuranetin (5,4'-dihydroxy-7methoxyflavanone) [13].

Sakuranetin was previously isolated from the leaves of Dodonaea angustifolia from Ngong forest and was reported to possessed good antifungal activity against $S$. cerevisiae with an MIC $<7.8$ $\mu \mathrm{g} / \mathrm{well}$, probably due to it lipophilic nature [16]. Besides that, sakuranetin isolated from Hebe cupressoides showed moderate antifungal activity against Trichophyton mentagrophytes where 60 $\mu \mathrm{g} / \mathrm{disk}$ of sakuranetin gave $3 \mathrm{~mm}$ zone of inhibition of $T$. mentagrophytes, but no inhibition of Candida albicans [13].

Compound (4) was isolated as dark yellow sticky solid. The UV spectrum of this compound displayed maximum absorption at $\lambda_{\max }$ 230, 287 and $332 \mathrm{~nm}$. The ${ }^{1} \mathrm{H}$ NMR spectrum of (4) displayed similar signal pattern to that of compound $(3)$ in the presence of methylene proton at $\delta_{\mathrm{H}} 3.19(1 \mathrm{H}, \mathrm{dd}, \mathrm{J}=12.8,16.8 \mathrm{~Hz}, \mathrm{H}-3 \mathrm{~b}), 2.76$ $(1 \mathrm{H}, \mathrm{dd}, \mathrm{J}=16.8,3 \mathrm{~Hz}, \mathrm{H}-3 \mathrm{a})$ and one oxymethine proton at $\delta_{\mathrm{H}}$ $5.45(1 \mathrm{H}, \mathrm{dd}, \mathrm{J}=12.6,3 \mathrm{~Hz}, \mathrm{H}-2)$ as the characteristic signals for flavanone. The difference between the ${ }^{1} \mathrm{H}$ NMR spectrum of $\mathbf{4}$ and 3 can be observed in ring $B$ where the signal of AABB spin system in 3 has been replaced by the signals of ABD spin system appeared at $\delta_{\mathrm{H}} 6.88\left(2 \mathrm{H}, \mathrm{s}, \mathrm{H}-5^{\prime} / \mathrm{H}^{\prime} 6^{\prime}\right)$ and $\delta_{\mathrm{H}} 7.05\left(1 \mathrm{H}, \mathrm{s}, \mathrm{H}-2^{\prime}\right)$, due to the presence of another hydroxyl group at C-3'. The ABD spin system of this compound gave out only two signals as the proton at C-5' and C-6' appeared at the same chemical shift as singlet. Lastly, one singlet signal located at a very downfield region at $\delta_{\mathrm{H}} 12.16(1 \mathrm{H}, \mathrm{s}, \mathrm{OH}-5)$ indicated a chelated $\mathrm{OH}$ at $\mathrm{C}-5$ due to hydrogen bonding between hydrogen atom of hydroxyl group and oxygen atom of carbonyl group at $\mathrm{C}-4$. The ${ }^{13} \mathrm{C}$ NMR APT displayed 16 carbon signals which correspond the structure of compound 4 with a total of 16 carbons. One aliphatic methylene carbon appeared at $\delta_{\mathrm{C}} 42.68(\mathrm{C}-3)$ and one oxymethine carbon at $\delta_{\mathrm{C}} 79.20(\mathrm{C}-2)$ proved that $(4)$ is a flavanone. The spectrum showed the presence of one methoxy group at $\delta_{\mathrm{C}} 55.32$. Other signals were attributed to five oxyaryl carbons $\left(\delta_{C} 145.29-167.97\right)$, two aromatic quartenary carbons $\left(\delta_{\mathrm{C}} 102.88\right.$ and 130.49$)$, five methine carbons $\left(\delta_{\mathrm{C}} 93.66,94.53,113.92,115.22\right.$ and 118.28) and carbonyl carbon $\left(\delta_{\mathrm{C}} 196.69\right)$. Based on all data and previous reported data, compound 4 was assigned as 7-O-methyleriodictyol [14].

From the previous study, 7-O-methyleriodictyol has been isolated from the resinous exudates of the plant Heliotropium sinuatum (Heliotropiaceae) and evaluated in vitro and in vivo antiviral activity against infectious salmon anemia virus (ISAV). The result showed that this compound was able to inhibit the infectivity of
ISAV in vitro assay with $\mathrm{EC}_{50}$ of $0.2 \mu \mathrm{g} / \mathrm{ml}$. While the in vivo study showed that this compound was able to $100 \%$ protect the fish infected with ISAV and keeping $100 \%$ fish viability despite the cytotoxicity of the compound displayed as $\mathrm{CC}_{50}$ of 12.80 $\mu \mathrm{g} / \mathrm{ml}[17]$.<smiles>CC(C)=C[I+]c1c(O)cc(O)c2c1OC(c1ccc(O)cc1)CC2=O</smiles>

1<smiles>[B]C(C)(O)C[Te+]c1c(O)cc2c(c1O)C(=O)CC(c1ccc(O)cc1)O2</smiles><smiles>[R]c1cc(C2CC(=O)c3c(O)cc(OC)cc3O2)ccc1O</smiles>

3. $\mathrm{R}=\mathrm{H}$

4. $\mathrm{R}=\mathrm{OH}$

Figure 1: 8-prenylnaringenin (1), 6-(3-hydroxy-3-methyl)naringenin (2), sakuranetin (3) and 7-O-methyleriodictyol (4)

\section{Conclusion}

Phytochemical study of the leaves of $M$. hypoleuca resulted in the isolation of four flavanones, which upon further elucidation by using modern spectroscopic techniques such as UV, IR NMR and MS confirmed that the flavanones are 8-prenylnaringenin (1), 6(3-hydroxy-3-methyl)naringenin (2), sakuranetin (3) and 7-Omethyleriodictyol (4)

\section{Acknowledgement}

The authors would like to thank The Ministry of Higher Education (MOHE), Malaysia for the research grant (RAGS/1/2014/SG01/UITM/4) and Prof. Nazip, a botanist from Universiti Teknologi MARA (UiTM) Shah Alam.

\section{References}

[1] A. Essiett and K. Ajibesin, "Antimicrobial Activities of Some Euphorbiaceae Plants Used in the Traditional Medicine of Akwa Ibom State of Nigeria," Ethnobot. Leafl., vol. 14, no. June 1, 2010 
pp. 654-64, 2010

[2] J. M. Joseph, "Phytochemistry and pharmacology of the genus Macaranga: A review," J. Med. Plants Res., vol. 8, no. 12, pp. 489503, Mar. 2014.

[3] R. Zakaria et al., "The distribution of," vol. 19, no. 2, pp. 91-99, 2008.

[4] N. S. Aminah, A. N. Kristanti, and M. Tanjung, "Antioxidant activity of flavonoid compounds from the leaves of Macaranga gigantea," vol. 6, no. July 2012, pp. 688-692, 2014.

[5] S. Phommart, P. Sutthivaiyakit, N. Chimnoi, S. Ruchirawat, and S. Sutthivaiyakit, "Constituents of the leaves of Macaranga tanarius," J. Nat. Prod., vol. 68, no. 6, pp. 927-930, 2005.

[6] T. Y. Lim, Y. Y. Lim, and C. M. Yule, "Evaluation of antioxidant, antibacterial and anti-tyrosinase activities of four Macaranga species," Food Chem., 2009.

[7] S. Kumazawa, M. Murase, N. Momose, and S. Fukumoto, "Analysis of antioxidant prenylflavonoids in different parts of Macaranga tanarius, the plant origin of Okinawan propolis," pp. 16-20, 2014.

[8] I. Zakaria, N. Ahmat, F. M. Jaafar, and A. Widyawaruyanti, "Flavonoids with antiplasmodial and cytotoxic activities of Macaranga triloba," Fitoterapia, vol. 83, no. 5, pp. 968-972, 2012.

[9] K. Matsunami et al., "Absolute configuration of (+)-pinoresinol 4 O-[6"-O-galloyl]-beta-D-glucopyranoside, macarangiosides E, and F isolated from the leaves of Macaranga tanarius.," Phytochemistry, vol. 70, no. 10, pp. 1277-85, Jul. 2009.

[10] R. M. Ngoumfo et al., "Inhibitory Effect of Macabarterin , a Polyoxygenated Ellagitannin from Macaranga barteri , on Human Neutrophil Respiratory Burst Activity,”pp. 1906-1910, 2008.

[11] C. Ito et al., "A new flavonoid and other new components from Citrus plants," Chem. Pharm. Bull., vol. 36, no. 9, pp. 3292-3295, 1988.

[12] S. Tahara, M. Tanaka, and W. Barz, "Fungal metabolism of prenylated flavonoids," Phytochemistry, vol. 44, no. 6, pp. 10311036, 1997.

[13] N. B. Perry, "Antiviral and Antifungal Flavonoids, plus a Triterpene, from Hebe cupressoides," Planta Med., vol. 60, pp. 491-492, 1994.

[14] L. Abu-Niaaj, M. Abu-Zarga, S. Sabri, and S. Abdalla, "Isolation and biological effects of 7-O-methyleriodictyol, a flavanone isolated from Artemisia monosperma, on rat isolated smooth muscles," Planta Med., vol. 59, no. 1, pp. 42-45, 1993.

[15] D.-S. Yang et al., "Cytotoxic prenylated bibenzyls and flavonoids from Macaranga kurzii," Fitoterapia, vol. 99, pp. 261-266, Dec. 2014.

[16] L. K. Omosa et al., "Antimicrobial flavonoids and diterpenoids from Dodonaea angustifolia," South African J. Bot., vol. 91, pp. 58-62, 2014.

[17] B. Modak, A. Rivas, and E. Vallejos, "Antiviral activity in vitro and in vivo of natural flavonoids isolated from Heliotropium sinuatum against infectious salmon anemia virus (ISAV)," Bol. Latinoam. y del Caribe Plantas Med. y Aromáticas., vol. 11, no. 4, pp. 377-384, 2012. 